\title{
Genomic and non-genomic pathways are both crucial for peak induction of neurite outgrowth by retinoids
}

\author{
Thabat Khatib', Pietro Marini', Sudheer Nunna', David R. Chisholm², Andrew Whiting ${ }^{2}$, Christopher Redfern³, \\ lain R. Greig ${ }^{1}$ and Peter McCaffery ${ }^{1 *}$ (i)
}

\begin{abstract}
Retinoic acid (RA) is the active metabolite of vitamin A and essential for many physiological processes, particularly the induction of cell differentiation. In addition to regulating genomic transcriptional activity via RA receptors (RARs) and retinoid $X$ receptors (RXRs), non-genomic mechanisms of RA have been described, including the regulation of ERK1/2 kinase phosphorylation, but are poorly characterised. In this study, we test the hypothesis that genomic and non-genomic mechanisms of RA are regulated independently with respect to the involvement of liganddependent RA receptors. A panel of 28 retinoids (compounds with vitamin A-like activity) showed a marked disparity in genomic (gene expression) versus non-genomic (ERK1/2 phosphorylation) assays. These results demonstrate that the capacity of a compound to activate gene transcription does not necessarily correlate with its ability to regulate a non-genomic activity such as ERK 1/2 phosphorylation. Furthermore, a neurite outgrowth assay indicated that retinoids that could only induce either genomic, or non-genomic activities, were not strong promoters of neurite outgrowth, and that activities with respect to both transcriptional regulation and ERK1/2 phosphorylation produced maximum neurite outgrowth. These results suggest that the development of effective retinoids for clinical use will depend on the selection of compounds which have maximal activity in non-genomic as well as genomic assays.
\end{abstract}

Keywords: Retinoic acid, Vitamin a, Erk1/2, Neurite outgrowth, RAR, Transcription, Non-genomic

\section{Background}

Retinoids are a family of natural or synthetic compounds that are analogues of vitamin A and its derivatives [1]. They are essential for numerous cellular activities including growth, proliferation and differentiation of a variety of tissues, and are necessary for central nervous system development, neuroplasticity and neurite outgrowth [2]. Most actions of retinoids are mediated by retinoic acid (RA), which is derived from retinol in a two-step enzymatic process via a retinaldehyde intermediate [3].

Retinoic acid (RA) has been described as a neurotrophic factor that binds to nuclear receptors (RAR and RXR),

\footnotetext{
* Correspondence: p.j.mccaffery@abdn.ac.uk

${ }^{1}$ School of Medicine, Medical Sciences and Nutrition, Institute of Medical Sciences, University of Aberdeen, Foresterhill, Aberdeen AB25 2ZD, Scotland, UK

Full list of author information is available at the end of the article
}

inducible ligand-activated transcription factors which regulate multiple physiological mechanisms at a genomic level $[4,5]$. In addition to this 'classical' mechanism, RA can exert non-genomic effects, mediated either by the RARs or independent of them [6-8]. Several studies have demonstrated that RA can activate kinases, such as ERK1/ 2 [9-13], which may play a role in cytoskeletal rearrangement and neurite outgrowth [14] in a number of cell types. The RA signalling pathway also regulates neurite outgrowth [15], a property demonstrated in several in vitro models including neuroblastoma cell lines and primary neuron cultures [16-21]. Whether this is a result of genomic or non-genomic effects, or a combination of such mechanisms, is unknown.

A large number of synthetic retinoids have been generated as agonists of the RA nuclear receptors, but, in contrast to the large number of published studies on their regulation of gene expression, very few studies

(c) The Author(s). 2019 Open Access This article is distributed under the terms of the Creative Commons Attribution 4.0 International License (http://creativecommons.org/licenses/by/4.0/), which permits unrestricted use, distribution, and 
have characterised the non-genomic action of retinoids in relation to their properties as RAR ligands. In this study, we test the hypothesis that genomic and non-genomic activities of retinoids are regulated independently using a diverse range of commercially-available, and novel RAR and RXR ligands for several of the different classes of RA receptors (RAR $\alpha / \beta / \gamma, R X R \alpha / \beta / \gamma)$ or ligands for RBP4. The properties of these ligands were compared with respect to activity in genomic (gene expression) assays and a non-genomic (ERK1/2 phosphorylation) assay, and their ability to induce neurite outgrowth.

\section{Methods}

\section{Retinoid solutions}

All-trans-RA (ATRA) (Sigma-Aldrich) was dissolved at a concentration of $0.1 \mathrm{M}$ in dimethyl sulfoxide (DMSO) under red light in a dark room, aliquoted into $0.6 \mathrm{ml}$ microtubes stored under nitrogen at $-70{ }^{\circ} \mathrm{C}$, and protected from light. Synthetic retinoids were dissolved in DMSO as $0.01 \mathrm{M}$ stock solutions and stored at $-20^{\circ} \mathrm{C}$, protected from light. A1120 and TTNPB were purchased from Sigma-Aldrich, CD2665 was purchased from Tocris; HX600 and DA124 were obtained from Dr. Kagechika (Tokyo) while fenretinide was obtained from Dr. Nimesh Mody (University of Aberdeen). Other synthetic retinoids and non-retinoid homologues were designed and synthesized as described previously [22-28]. The molecular structures of the RAR and RXR ligands used are shown in Fig. 1. The majority of the compounds are effective activators of RARs, except for A1120 (a RBP4 ligand), HX600 and DA124 (RXR agonists), CD2665 (RAR $\beta / \gamma$ antagonist) and DC324, DC329 and DC303, which exhibit extended structures compared to their shorter analogues (DC271, DC375 and EC23, respectively) that significantly reduce their binding affinities for the RARs.

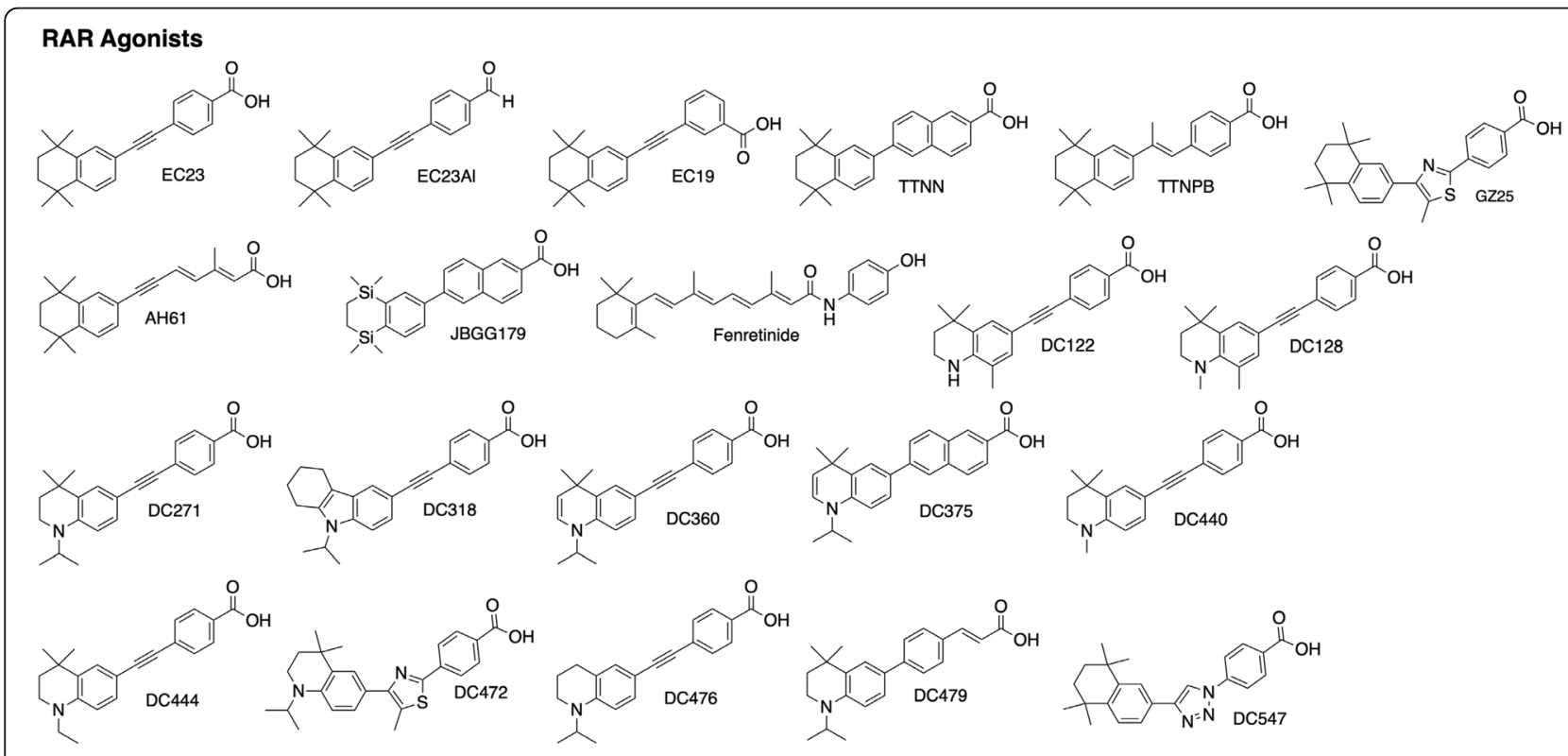

RXR Agonists<smiles>Cc1ccc(-c2nc3c(cc2-c2ccc(C(=O)O)cc2)C(C)(C)CCC3(C)C)cc1</smiles><smiles>CC1(C)CCC(C)(C)c2cc(N(CC3CC3)c3ccc(C(=O)O)cc3)ccc21</smiles>

RBP4 Antagonist<smiles>O=C(O)c1ccccc1NC(=O)N1CCC(c2ccccc2C(F)(F)F)CC1</smiles>

Poor RAR Agonists

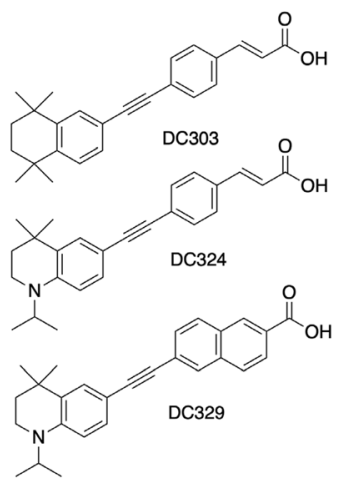

RAR Antagonist

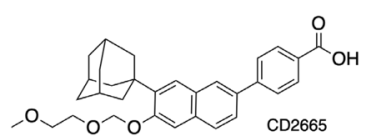

Fig. 1 Retinoids used in the study grouped into those that are RAR agonists, RXR agonists, RAR antagonists, poor RAR agonists and antagonists for RBP4 


\section{Cell culture}

Sil-15 cells [29] were used in the X-Gal based RA reporter assay, described below, to measure the transcriptional activity of ATRA and other RAR and RXR ligands. This cell line was derived [29] from F9 teratocarcinoma cells transfected with a plasmid containing the LacZ gene under the control of a promoter linked to the RAR $\beta$ RARE [30, 31]. Sil-15 cells were cultured at $37^{\circ} \mathrm{C}$ with $5 \% \mathrm{CO}_{2}$ in T-75 flasks in Dulbecco's Modified Eagle's Medium (DMEM; Thermo Fisher Scientific) containing 10\% fetal calf serum (FCS; Thermo Fisher Scientific), $0.8 \mathrm{mg} / \mathrm{ml}$ G418 disulfate salt (Geneticin, Sigma-Aldrich) to maintain selection for the LacZ plasmid; cells were passaged twice a week using 0.05\% Trypsin-EDTA.

SH-SY5Y cells [32] were used in the neurite outgrowth, ERK phosphorylation and RA genomic activity assays. The cells were treated with varying concentration of retinoids for each assay depending on the results of previously performed pilot studies. These cells are a third subclone of the SK-N-SH neuroblastoma cell line [33]. SH-SY5Y cells were grown in DMEM containing 10\% FCS at $37^{\circ} \mathrm{C}$ with $5 \% \mathrm{CO}_{2}$. The medium was changed three times a week and the cells were passaged at $70 \%$ confluence using $0.05 \%$ trypsin-EDTA. The passage number used for each experiment was no higher than 30 .

\section{X-gal based RA reporter assay}

Sil-15 cells were used to detect and quantify the transcriptional activity of retinoids added to the medium by monitoring $\beta$-galactosidase activity produced by the reporter cells. 96-well plates were coated with $0.1 \%$ gelatin for at least $2 \mathrm{~h}$ at $37^{\circ} \mathrm{C}$, washed twice with PBS, wrapped with parafilm and stored at $4{ }^{\circ} \mathrm{C}$ until use. Sil-15 cells were removed from stock culture flasks by trypsinization, counted and plated at 100,000 cells per well in the pre-coated 96-well plates. After attachment overnight in DMEM containing 10\% FCS, the medium was replaced with fresh DMEM/ $10 \%$ FCS and serial dilutions of retinoid ligands, prepared in DMEM containing 10\% FCS, were added at concentrations from $10^{-6} \mathrm{M}$ to $10^{-14} \mathrm{M}$. The plates were incubated overnight at $37^{\circ} \mathrm{C} / 5 \% \mathrm{CO}_{2}$. All concentrations for the ATRA standard curve and the other retinoid ligands were tested in triplicate. The next day, the assay plates were washed twice with PBS, fixed with $100 \mu \mathrm{l}$ per well of $1 \%$ glutaraldehyde and $1 \mathrm{mM} \mathrm{MgCl}$ in PBS for $15 \mathrm{~min}$, washed twice with PBS and $\beta$-galactosidase activity detected by adding to each well $100 \mu \mathrm{l}$ of freshly-prepared $0.2 \% \mathrm{X}-\mathrm{Gal}$ in $1 \mathrm{mM} \mathrm{MgCl} 2,3.3 \mathrm{mM}$ potassium ferricyanide and $3.3 \mathrm{mM}$ potassium ferrocyanide in PBS. Plates were incubated for $6 \mathrm{~h}$ at $37^{\circ} \mathrm{C}$ in $5 \% \mathrm{CO}_{2}$ and colour change at $650 \mathrm{~nm}$ measured on an Emax Precision Microplate Reader (Molecular Devices).

\section{Gene expression analysis}

Total RNA was extracted from SH-SY5Y cells treated with $10 \mathrm{nM}$ retinoid ligands for $24 \mathrm{~h}$ using a Qiagen RNeasy mini kit according to the manufacturer's protocol. An extra DNAse digestion step was carried out during RNA purification to remove DNA contamination. cDNA was synthesized from $250 \mathrm{ng}$ total RNA using High qScript cDNA Synthesis master mix. qPCR reactions using PerfeCTa SYBR Green SuperMix were performed on a Roche LightCycler 480 and analyzed using LightCycler $480 \quad 1.5$ software. Primers spanning exon-exon junctions were designed using Primer-BLAST [34] for CYP26A1 (CACCGTACGGGTGA TGGGCG, GCTGGCCAGTGGACCGACAC), RAR $\beta$ (GCTTAATCTGTGGAGACCGCCAGG, TGTGAGGCT TGCTGGGTCGT), and GAPDH (TCTTTTGCGTCGCC AGCCGA, AGTTAAAAGCAGCCCTGGTGACCA) genes. Standard curves and blank controls were run for all sets of primers tested. A housekeeping gene was chosen for normalization by prescreening a range of genes with experimental samples and choosing the one showing least variability between samples, which in this case was GAPDH.

\section{ERK1/2 phosphorylation screening using the AlphaLISA ${ }^{\oplus}$ SureFire ${ }^{\circledast}$ Ultra assay}

The ability of ATRA and other RAR and RXR ligands to phosphorylate ERK1/2 was determined in SH-SY5Y cells using the AlphaLISA ${ }^{\circ}$ SureFire ${ }^{\circ}$ Ultra ERK1/2 kit (PerkinElmer). In this assay, SH-SY5Y cells $(100,000$ cells/well) were plated in 96-well plates and serum-starved in DMEM for $24 \mathrm{~h}$. Retinoids were tested at concentrations from $10^{-5} \mathrm{M}$ to $10^{-11} \mathrm{M}$ and at a final concentration of $0.1 \%$ DMSO in the medium. SH-SY5Y cells were assayed in serum-free DMEM and stimulated for $30 \mathrm{~min}$ (determined from a time course experiment) at $37{ }^{\circ} \mathrm{C}$. At the end of the assay, the medium was removed, and cells were lysed with $50 \mu \mathrm{l}$ of freshly prepared $1 \mathrm{X}$ lysis buffer supplied in the kit. The 96-well plate was agitated on an orbital shaker SO1 (Stuart Scientific) at approximately $350 \mathrm{rpm}$ for $10 \mathrm{~min}$ at room temperature. In the meantime, the activation buffer was diluted 25 -fold in the reaction buffers. Under green light in a dark room the acceptor beads were diluted 50-fold in the freshly prepared reaction mix while the donor beads were diluted 50-fold in dilution buffer to obtain two final reaction mixtures. $10 \mu \mathrm{l}$ of cell lysate was then transferred to the wells of a 384-well white Proxiplates plate (PerkinElmer) and $5 \mu$ of each prepared acceptor and donor reaction mixtures was added above the wells while still under green light in the dark room. Plates were next wrapped with aluminium foil and incubated at room temperature for at least 3 $\mathrm{h}$ and read with the Envision system (PerkinElmer Life Sciences) using AlphaScreen ${ }^{\bullet}$ settings. 


\section{Neurite outgrowth assay}

$16 \mathrm{~mm}$ glass coverslips were acid treated in a mixture of $69 \%$ nitric acid and $37 \%$ hydrochloric acid in a 2:1 ratio for $2 \mathrm{~h}$. The coverslips were then washed extensively with MilliQ deionised water until the $\mathrm{pH}$ of the water reached 5.5-6. Until needed, the coverslips were stored in a jar containing $70 \%$ ethanol. The coverslips were put on a $70 \%$ ethanol-soaked tissue paper under the cell culture hood to dry. The coverslips were then placed in the wells of 12-well plates. After that they were coated by addition of $1 \mathrm{ml}$ of poly-L-lysine (PLL) solution above each coverslip in the well. The final concentration of PLL solution used for coating was $0.002 \%$ and the incubation time was $2 \mathrm{~h}$ at $37^{\circ} \mathrm{C}$. Two washes with sterile PBS followed and afterwards the coverslips were air dried under sterile conditions.

SY-SY5Y cells were removed from stock flasks by trypsinization, counted and plated at 10,000 cells/well in 12-well plates containing acid-treated/PLL-coated coverslips. The plates were maintained at $37^{\circ} \mathrm{C}$ in a humid atmosphere containing $5 \% \mathrm{CO}_{2}$ for $24 \mathrm{~h}$. Then, each retinoid was added to the medium and tested at two different concentrations, $10 \mu \mathrm{M}$ and $10 \mathrm{nM}$, with a final DMSO concentration of $0.01 \%$ or $0.0001 \%$, respectively. The plates incubated for 5 days at $5 \% \mathrm{CO}_{2} / 37^{\circ} \mathrm{C}$. All retinoid concentrations were tested in triplicate.

After retinoid treatment, SH-SY5Y cells on coverslips were washed twice in PBS, fixed in $4 \%$ paraformaldehyde (PFA) for $20 \mathrm{~min}$ at room temperature, followed by two washes with PBS. Coverslips were stored at $4{ }^{\circ} \mathrm{C}$ in PBS until stained. For immunocytochemical staining of neurites, cells on coverslips were washed three times in PBS, and incubated in blocking solution (10\% donkey serum and $0.1 \%$ Triton $\mathrm{X}-100$ in PBS) for $1 \mathrm{~h}$ at room temperature. Cells were then labelled by incubation overnight at $4{ }^{\circ} \mathrm{C}$ with $\beta$-III tubulin primary antibody (Sigma-Aldrich) diluted 1:1000 in blocking buffer, washed three times with PBS containing 0.1\% Triton X-100 solution (PBST) before incubation with anti-mouse monoclonal secondary antibody (1:300 in PBST; Jackson Immunoresearch) for $2 \mathrm{~h}$ at room temperature. Finally, after three washes in PBST and a final wash in PBS, the coverslips were mounted on slides and stored at $4{ }^{\circ} \mathrm{C}$.

ImageJ software with the NeuronJ plugin was used to quantify neurite outgrowth on stained cells. For each experiment, 10 different randomly selected images were taken from each cover slip using a Nikon Eclipse E400 fluorescence microscope. Each image was converted into an 8-bit image (necessary for the NeuronJ plugin) and optimised with the brightness and contrast tool in GIMP (GNU Image Manipulation Program). For each image, individual traces were drawn for each clearly-identifiable neurite using the tracing tool in the NeuronJ plugin.
Neurite length was measured in pixels and transformed into the corresponding length in $\mu \mathrm{m}$ depending on the magnification used. The average neurite length for each image was calculated by dividing total neurite length by the total number of neurites per image. Ten images per cover slip were measured and the mean calculated for the coverslip overall. Coverslips were in triplicate for each retinoid and concentration.

\section{Cell number assay}

SH-SY5Y cells were plated on acid-treated/PLL-coated coverslips, treated with retinoids as described previously in the neurite outgrowth assay section, 4\% PFA fixed and stained with bisbenzimide dye $(1 \mathrm{mg} / \mathrm{ml})$. For each experiment, 10 different randomly selected images were taken from each cover slip using a Nikon Eclipse E400 fluorescence microscope. The number of cells were then counted in each image manually, identifying each cell from its bisbenzimide-labelled nucleus. Ten images per cover slip were measured and the mean calculated for the coverslip overall. Coverslips were in triplicate for each retinoid and concentration.

\section{Statistical analysis}

All data are presented as mean \pm SEM of three independent experiments with biological triplicates. Statistical analyses were performed in Microsoft Office Excel 2017, GraphPad Prism 7.0c version (Prism, GraphPad Software, San Diego, CA) and R version 3.3.1 (R Core Team, 2016) [35]. Gene expression and Neurite Outgrowth data were analysed by Student's t-test or one-way ANOVA with Newman-Keuls multiple comparison test as appropriate; $P$ value $<0.05$ was considered statistically significant. " $P<0.05$, $* P<0.01$, ***: $P<0.001$, ***** $P<0.0001$. Data for X-Gal and ERK1/2 phosphorylation were analysed using sigmoidal dose-response analysis of log (agonist) versus response curve (stimulation). Non-parametric (Spearman) and parametric (Pearson) correlation analyses were used to compare cell responses, and asymptotic Wilcoxon-Mann-Whitney tests for non-parametric two-way comparisons of neurite length and cell number, where appropriate. Non-parametric correlation analyses were used for comparisons involving transcriptional data so that outliers could be included without bias. The results of analyses were presented as $\mathrm{E}_{\max }$ and $\mathrm{EC}_{50}$ with $95 \%$ confidence interval limits (95\% CI).

\section{Results}

\section{Genomic activity of retinoids}

To quantify genomic (transcriptional regulation) activity, the Sil-15 RA reporter cell line, in which X-gal expression is driven by a RAR $\beta$ RARE, was used to assay retinoids at concentrations ranging from $10^{-6} \mathrm{M}$ to $10^{-14}$ 
M. In these assays (Fig. 2), the $\mathrm{EC}_{50}$ value represents the half-maximal effective concentration (potency) and is related to the affinity for the receptor; the maximum stimulation, defined by the $E_{\max }$ value, is a measure of the compound efficacy. Of the 28 retinoids tested, nine (HX600, DA124, EC19, CD2665, DC375, DC324, DC329, DC476 and DC479) did not have any genomic activity compared to ATRA. However, 19 compounds were effective in inducing a genomic response. Three retinoids, EC23, TTNPB and GZ25, had significantly lower $\mathrm{EC}_{50}$ than ATRA and TTNN, DC128, AH61, and DC271 had similar potencies to ATRA; the other retinoids had significantly higher $\mathrm{EC}_{50}$ values than ATRA (Fig. 2).

In addition, the compounds varied in their efficacy $\left(E_{\max }\right)$. Not all compounds with higher potency compared to ATRA also exhibited higher efficacy, and vice versa. For example DC271 and TTNPB had lower $E_{\max }$ values, even though their $\mathrm{EC}_{50}$ values were lower or the same as ATRA. EC23Al (the aldehyde of EC23) showed a significantly higher $E_{\max }$ while the $\mathrm{EC}_{50}$ was greater compared to ATRA. Moreover, GZ25 exhibited a significantly higher $\mathrm{E}_{\max }$ compared to ATRA, and also showed greater potency than ATRA. The potency and efficacy of each ligand along with the $95 \%$ confidence intervals (CI) in inducing a genomic activity are summarised in Additional file 1 :Table S1.

To confirm the activity of these retinoids on endogenous transcriptional regulation in the SH-SY5Y cell line used for neurite outgrowth and non-genomic activity assays, two genes with well-defined RAREs in their promoters were investigated: $R A R \beta$ and CYP26A1 [30, 3638 ]. In these assays, the fold change in $R A R \beta$ and CYP26A1 gene expression in SH-SY5Y cells treated with $10 \mathrm{nM}$ concentrations of RAR and RXR ligands were compared to a DMSO control (Fig. 3). EC23, AH61, EC23Al, TTNN and JBGG179 all had greater potency than ATRA at inducing CYP26A1 and RAR $\beta$. DC444 induced $C Y P 26 A 1$ and $R A R \beta$ gene expression to almost the same extent as ATRA. Fenretinide, DC440 and DC271 induced CYP26A1 and RAR $\beta$ but were weaker than ATRA, while DC360 and DC476 only induced $R A R \beta$. The other RAR and RXR ligands did not activate $C Y P 26 A 1$ or $R A R \beta$. These gene expression results were generally comparable to the results obtained with the X-Gal RA based reporter assay; a key result is that GZ25 and EC23 were stronger in their genomic activity compared to ATRA at low concentrations in both assays.

\section{Non-genomic activity (ERK1/2 phosphorylation) induced by retinoids in SH-SY5Y cells}

SH-SY5Y cells have been reported to respond in a non-genomic manner to the nuclear receptor ligand, ATRA, with an increase in ERK1/2 activity [39-41].
Therefore, changes in ERK1/2 activity, detected as ERK1/2 phosphorylation, in response to retinoids were compared to ATRA as a positive control (Fig. 4). In these experiments we could confirm that ATRA was a strong activator of ERK1/2 kinase phosphorylation [40, 42, 43]. Of the other retinoids, nine (A1120, CD2665, HX600, GZ25, DC329, DC440, DC472, DC476 and TTNN) induced ERK1/2 phosphorylation with an $\mathrm{EC}_{50}$ that was significantly lower than ATRA. Five ligands, AH61, EC23, DA124, DC128 and DC324, had $\mathrm{EC}_{50}$ values for ERK1/2 phosphorylation similar to ATRA. The remaining retinoids were less potent compared to ATRA (Fig. 4).

With respect to efficacy, 13 of the RAR and RXR ligands (EC23, EC23Al, HX600, GZ25, DC122, DC271, DC303, DC360, DC440, DC472, DC476, DC479 and DC547) had $E_{\max }$ values significantly higher than ATRA. Six retinoids, AH61, A1120, CD2665, DA124, DC324 and TTNN, had similar efficacies to ATRA. The efficacy of the rest of the retinoids was significantly lower than ATRA. The potency and efficacy of each ligand along with the 95\% confidence intervals (CI) in inducing ERK1/2 phosphorylation are summarised in Additional file 1 :Table 1.

\section{Neurite outgrowth and number of SH-SY5Y cells increased by retinoids}

The SH-SY5Y cell line can be induced by ATRA towards a neuronal phenotype and is used as a model to study neuronal differentiation and neurite outgrowth [44]. In addition, ATRA stimulates an increase in cell number in SH-SY5Y cell cultures [9]. Each retinoid was tested at two different concentrations, $10 \mu \mathrm{M}$, as an assay of relative efficacy, and $10 \mathrm{nM}$ as a measure of relative potency (Figs. 5 and 6).

As in previous studies, ATRA at $10 \mu \mathrm{M}$ induced neurite outgrowth of SH-SY5Y cells [45]. EC23, AH61 and GZ25 induced neurite outgrowth of SH-SY5Y cells at the two tested concentrations, and with substantially higher relative potency compared to ATRA. Fenretinide induced death of almost all the SH-SY5Y cells at $10 \mu \mathrm{M}$ concentration; SH-SY5Y cells have a particular sensitivity to fenretinide which induces apoptosis in a concentration dependent manner [46-48]. Conversely, fenretinide significantly induced neurite outgrowth at $10 \mathrm{nM}$ concentration. A1120 and DC271, DC128 and TTNN also induced neurite outgrowth of the SH-SY5Y cells at the two tested concentrations. TTNPB, DC360, DC303, DC122, DC440, EC23Al and DC547 induced neurite outgrowth at $10 \mu \mathrm{M}$ concentration only. HX600, DA124, DC318, CD2665, DC375, DC324, DC329, DC476, JBGG179, DC479 and EC19 did not have visible effects on neurite outgrowth in the SH-SY5Y cells at either concentration. The fold increase in neurite outgrowth 

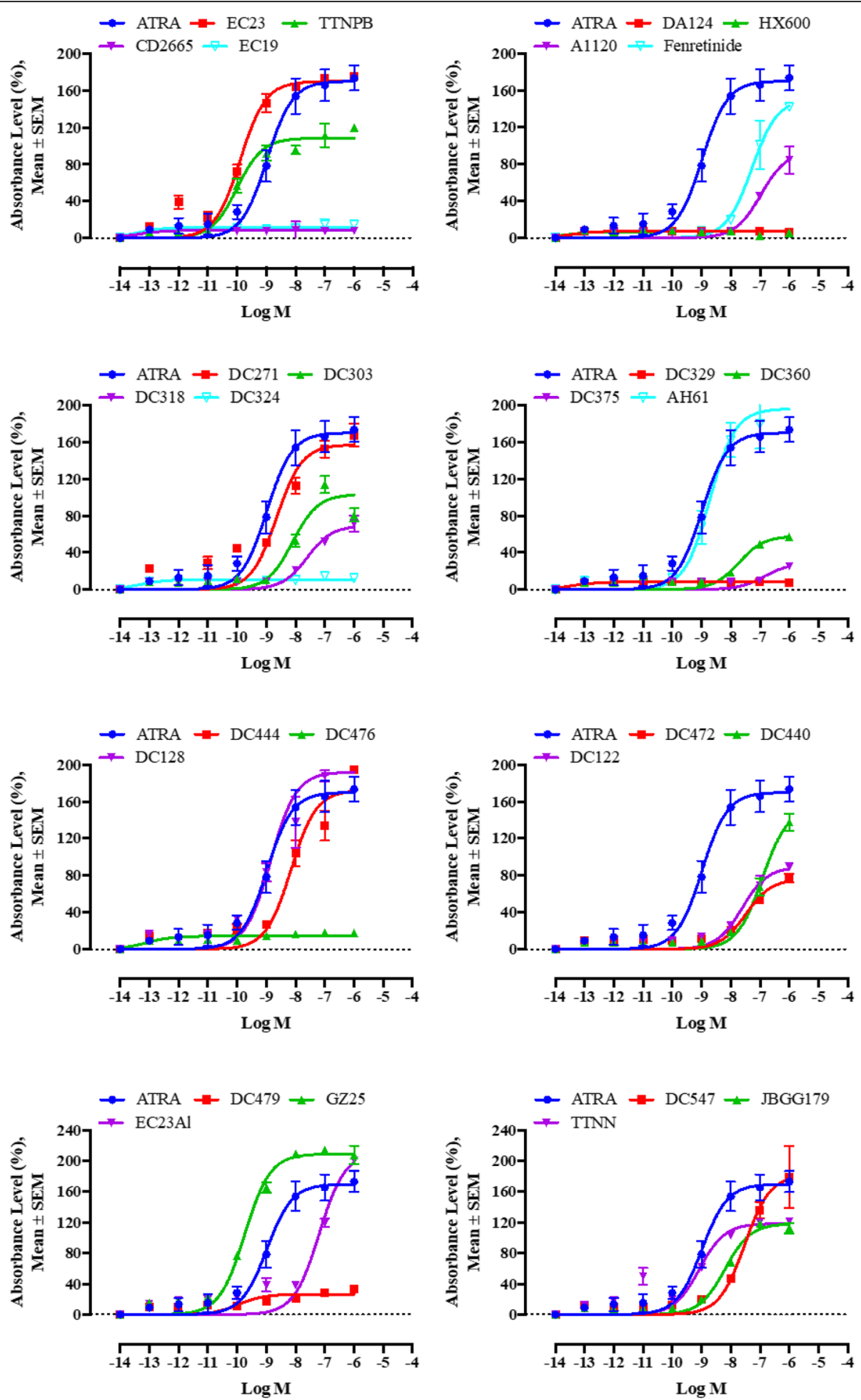

Fig. 2 The concentration-response graph for log (agonist) vs. sigmoidal dose-response in evaluating ATRA versus retinoids in inducing genomic response of Sil-15 reporter cells. Absorbance values of different retinoid doses were measured at $650 \mathrm{~nm}$ and analysed using sigmoidal doseresponse curves. Shown are average absorbance of three independent experiments. Error bars indicate standard error of the mean (SEM). Statistically significant differences are indicated by non-overlapping $95 \% \mathrm{Cl}$ 


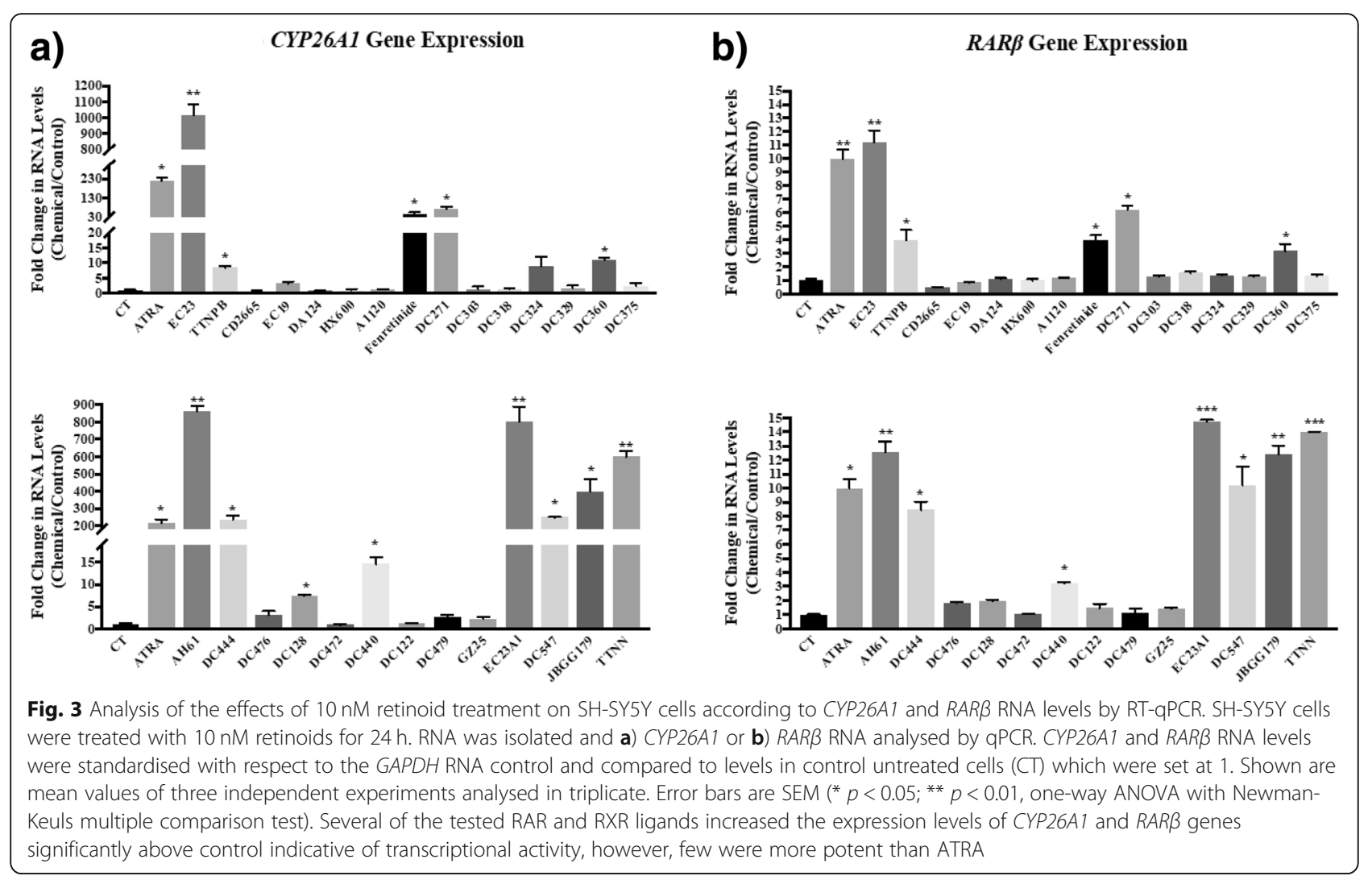

induced by each ligand is summarised in Additional file 1: Table S1. The number of neurites per cell was also determined but this did not change significantly between retinoid treatment (data not shown).

Cell number was measured in SH-SY5Y cultures after each retinoid treatment (Fig. 6). ATRA, EC23, AH61, GZ25, TTNPB, EC19, A1120, DC271, DC360, DC128, DC440, EC23AL and TTNN increased SH-SY5Y cell number significantly at the two tested concentrations. EC23, AH61 and GZ25 increased the number of cells at $10 \mathrm{nM}$ concentration with significantly higher relative potency compared to ATRA. DC375 and DC472 increased SH-SY5Y cells significantly at $10 \mathrm{nM}$ concentration only. The rest did not have significant effects on the number of SH-SY5Y cells at either concentration.

Overall, there was a significant positive correlation between the increase in neurite length and cell number induced by the retinoids (correlation coefficient, Pearson, $0.77 ; P<0.00001$ ), while there was no significant correlation between ERK1/2 activity $\left(E_{\max }\right)$ and transcriptional activation activity $\left(E_{\max }\right)$ of the retinoids tested $(n=28$, Spearman $\mathrm{r}=0.2, P=0.29)$. This suggests that the genomic and non-genomic properties of the retinoids tested are independent.

\section{Relationship of ERK1/2 kinase activity to neurite outgrowth and cell number}

For retinoids that increased neurite length there was no significant correlation between ERK activity (Efficacy, $\left.E_{\max }\right)$ and neurite length (correlation coefficient, Pearson, $0.28 ; P=0.3$ ); conversely, there was a significant positive correlation between neurite length and transcriptional activity $\left(E_{\max }\right.$, correlation coefficient, Spearman, 0.6, $P=0.014$ ). This suggests a proportional relationship between genomic properties of retinoids and increasing neurite length but a lack of such proportional relationship with respect to ERK1/2 activity as a non-genomic effect. For cell number, using all data (including retinoids that did not increase neurite length), there was no significant correlation with ERK activity (correlation coefficient, Pearson, $0.315 ; P=0.1$ ), but, as with neurite length, there was a significant correlation between cell number and transcriptional activity (correlation coefficient, Spearman, 0.745, $P<0.0001$ ), again suggesting that the genomic effects of retinoids are important determinants of cell responses. Plots showing correlation analysis are illustrated in Additional file 2: Figure S1.

For retinoids that increased neurite length, significantly shorter neurites were induced by retinoids $(n$ 

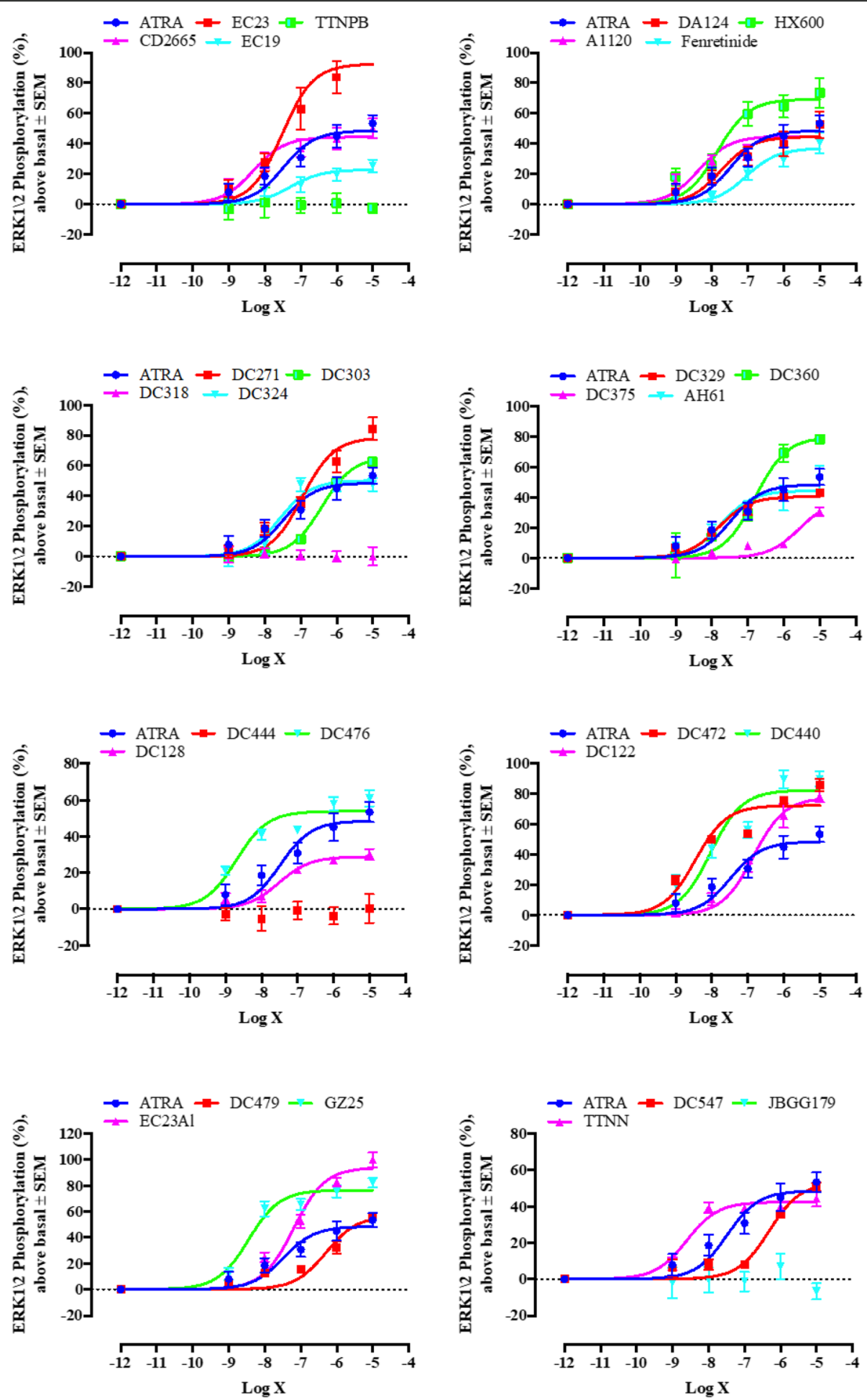

Fig. 4 Sigmoidal concentration-response graphs for induction of ERK1/2 phosphorylation in SH-SY5Y cells. Absorbance values of different retinoid doses were measured at $570 \mathrm{~nm}$. The average absorbance in three independent experiments are shown. Error bars indicate SEM. There was a statistical difference in the potency ( $E_{50}$ ) between ATRA and (A1120, CD2665, HX600, GZ25, DC329, DC440, DC472, DC476, TTNN), and the efficacy $\left(E_{\text {max }}\right)$ between ATRA and (EC23, EC23Al, HX600, GZ25, DC122, DC271, DC303, DC360, DC440, DC472, DC476, DC479) calculated by the non-overlapping $95 \% \mathrm{Cl}$ 


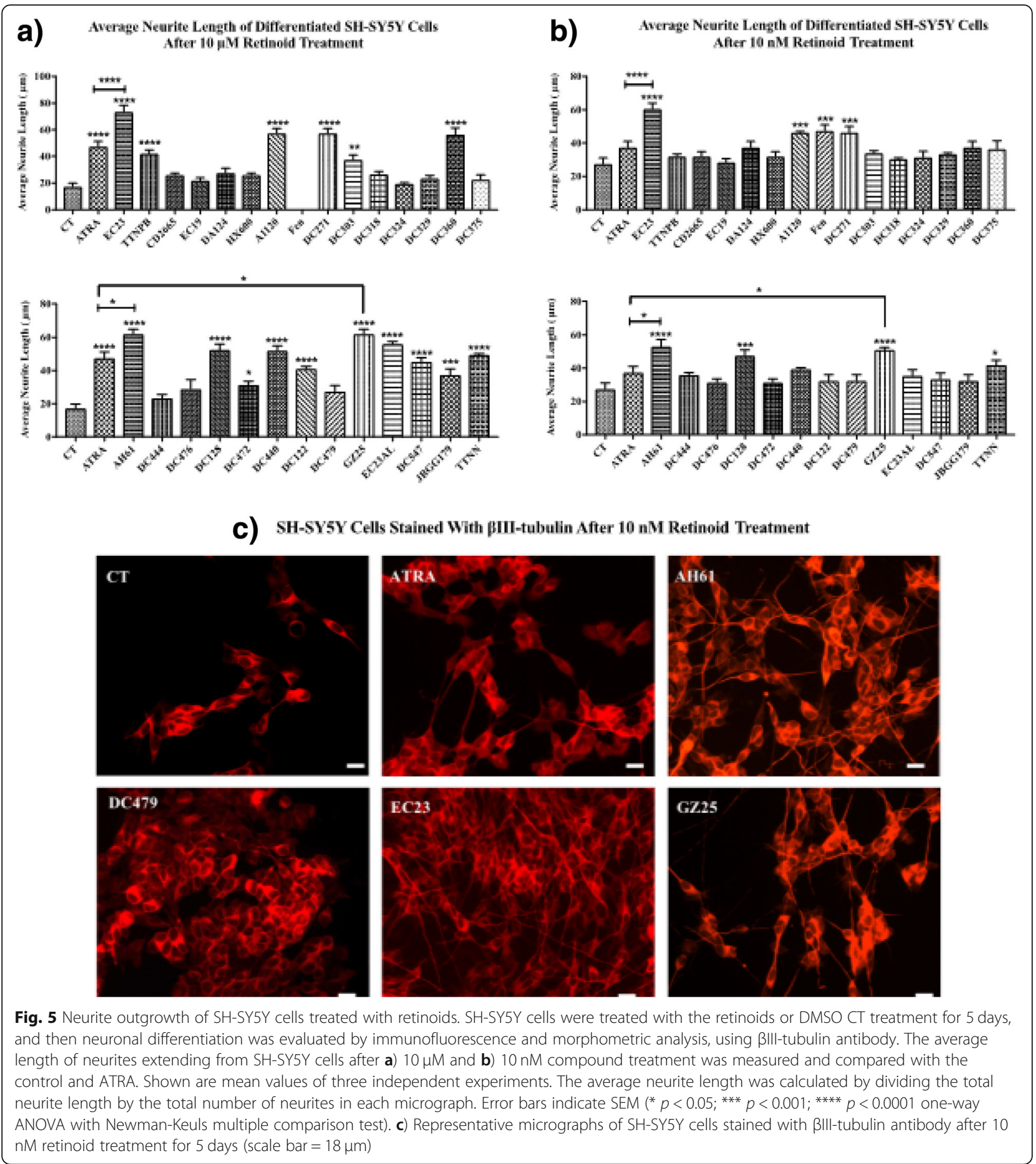

=4) that had no detectable ERK1/2 activity compared to retinoids $(n=16)$ that had activity in both the ERK1/2 and transcriptional assays (Asymptotic Wilcoxon-Mann-Whitney Test; $P=0.012$ ). However, this was not the case for increases in cell number (Asymptotic Wilcoxon-Mann-Whitney Test; $P=$ $0.11)$.
To confirm that non-genomic activity is necessary for retinoids to promote neurite outgrowth, kinase activity was blocked using the MEK1/2 inhibitor U0126 (Tocris) at a concentration of $10 \mu \mathrm{M}$. The MEK1/2 inhibitor U0126 produced a significant decrease in the neurite outgrowth induced by ATRA and EC23 (Fig. 7); neurite outgrowth was decreased 2.7-fold and 3.3-fold in ATRA- 


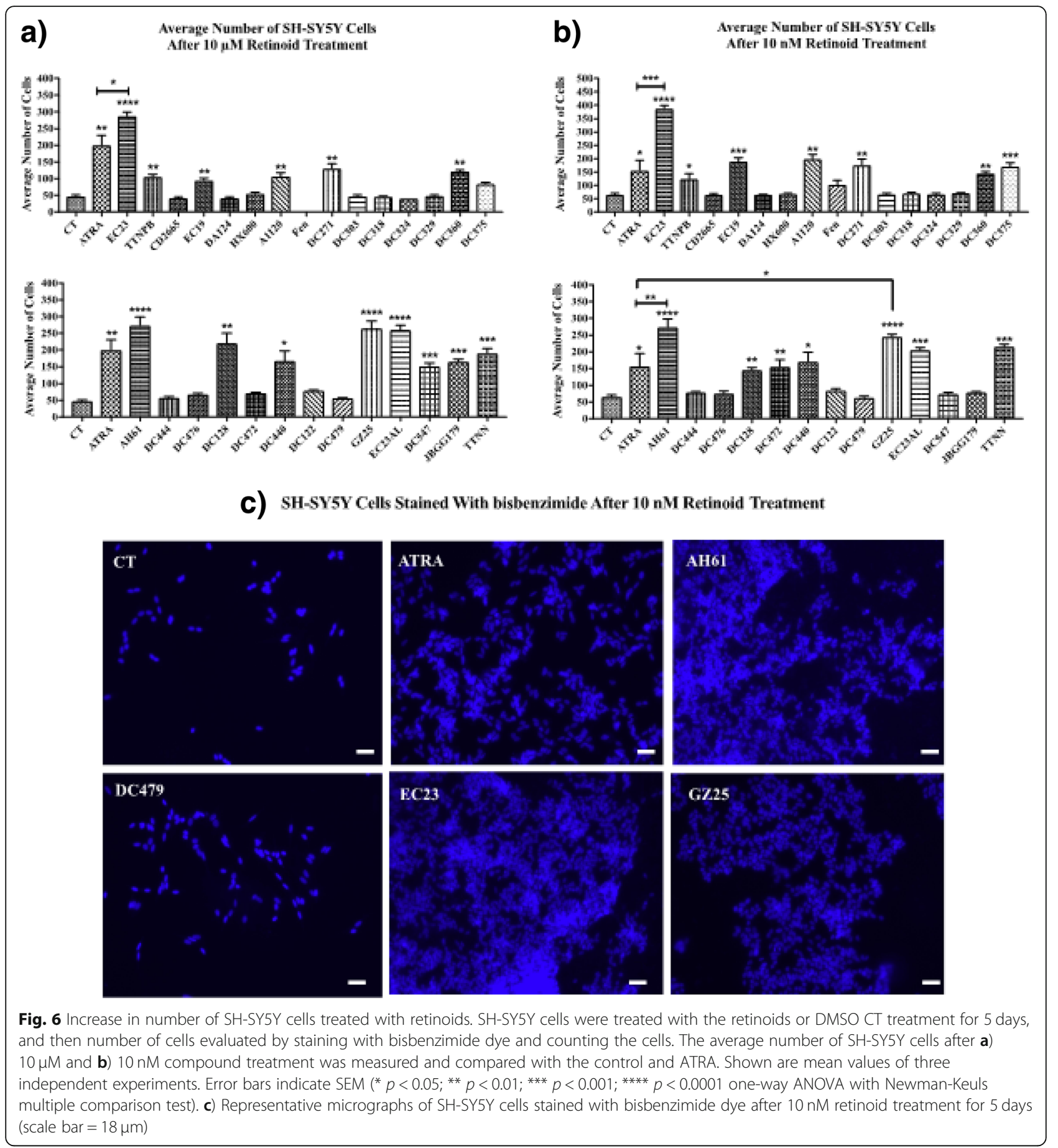

and EC23-treated cells, respectively, after adding the MEK1/2 inhibitor. MEK1/2 lies upstream of the ERK signaling pathway and these results imply that the MEK1/2 - ERK1/2 kinase signal transduction pathway is important in facilitating ATRA-induced neurite outgrowth. In addition, MEK1/2 inhibitor did not have an effect on SH-SY5Y cell number compared to control (results not shown).

\section{Discussion}

Since the discovery of RA receptors as members of the nuclear receptor family of transcriptional regulators [49], the emphasis on retinoid function has been on their control of gene expression and a large number of synthetic retinoids have been generated [50] and investigated for their genomic activating properties. However, nuclear receptors can also have important non-genomic 

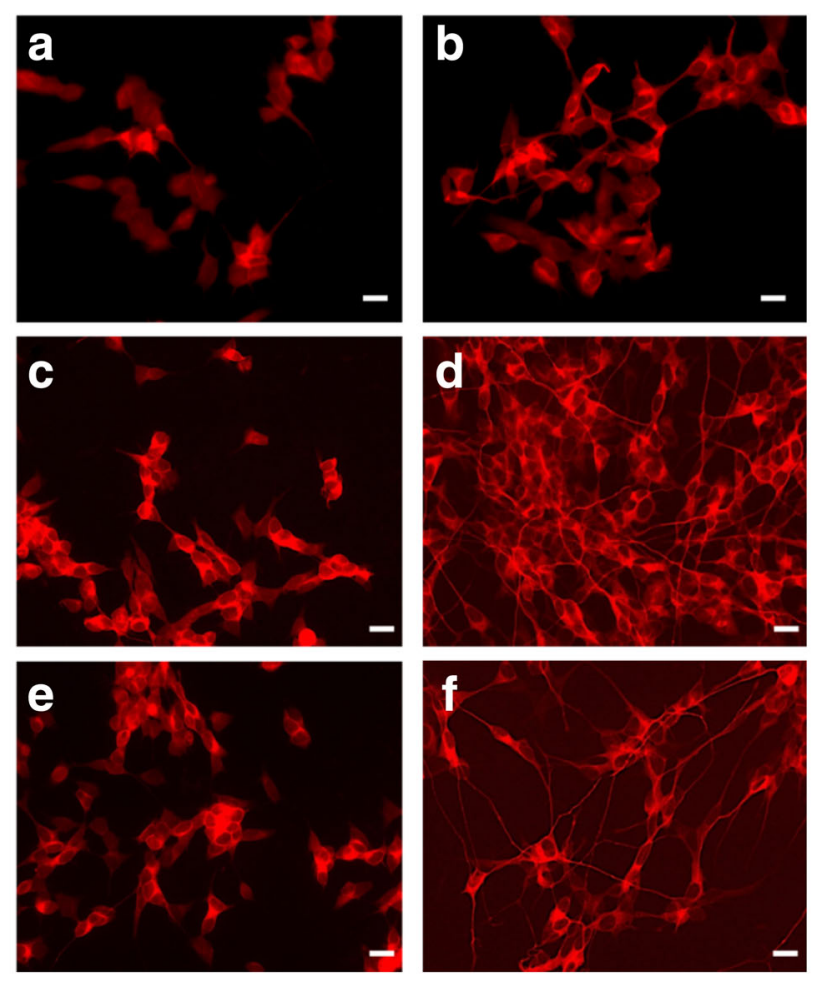

Average Neurite Length of Differentiated SH-SY5Y Cells

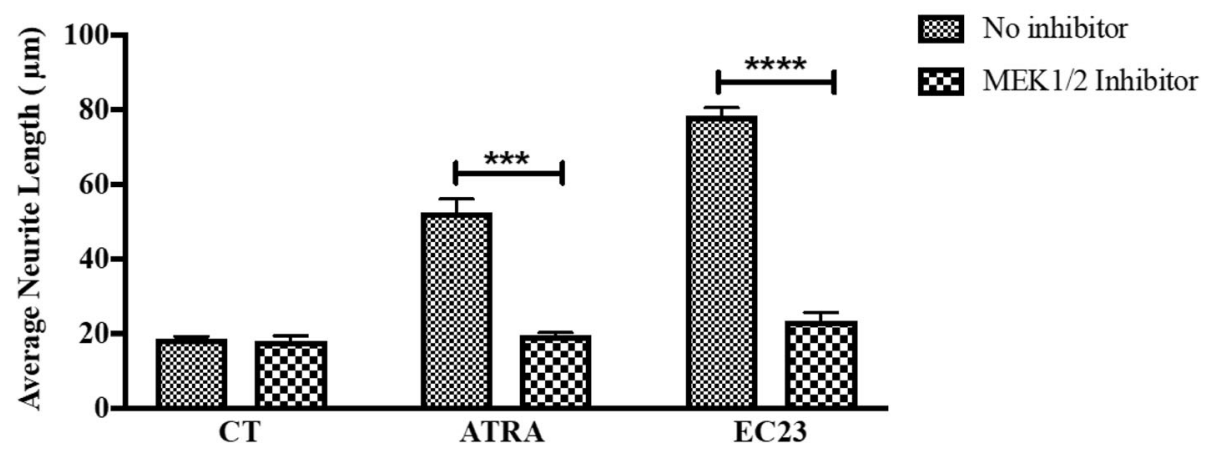

Fig. 7 MEK1/2 kinase involvement in neurite outgrowth. SH-SY5Y cells were treated with ATRA and EC23 with/without U0126 MEK1/2 inhibitor for 5 days, and then neuronal differentiation was evaluated by immunofluorescence and morphometric analysis using $\beta I I I$ tubulin antibody. Neurite outgrowth was significantly reduced after applying U0126. Typical micrographs are shown in a) DMSO CT, b) MEK1/2 inhibitor, c) $10 \mu M$ of ATRA and MEK1/2 inhibitor, d) $10 \mu \mathrm{M}$ ATRA, e) $10 \mu \mathrm{M}$ of EC23 and MEK1/2 inhibitor, f) SH-SY5Y cells with $10 \mu \mathrm{M}$ EC23 (scale bar $=18 \mu \mathrm{m})$. Error bars indicate SEM of three biological replicates $\left({ }^{* *} p<0.01 ;{ }^{* * *} p<0.001 ;{ }^{* * *} p<0.0001\right.$ two-way ANOVA with Sidak's multiple comparison test)

actions [7, 51]. Such non-genomic roles have also been proposed for the RA receptors, although the topic has remained relatively unexplored and is complex, with RA controlling multiple non-genomic pathways including regulation of kinases [52] and protein translation [53].

In this study, the 28 retinoids investigated varied in their genomic activity according to the differences in molecular structure and their relative affinities for the different receptors. For example, EC23 and GZ25, compounds that exhibit strong binding affinities for the
RARs, were the most potent, followed by TTNPB, DC128, AH61, and DC271. Conversely, compounds with low affinity for the RARs, such as the RXR ligands DA124 and HX600 or the extended DC324 and DC329, did not induce a genomic response. In these respects, the results from the X-gal activity assays and the genomic activity of the compounds as inducers of $R A R \beta$ and CYP26A1 expression in SH-SY5Y cells were comparable, and the most potent ligands in the X-Gal reporter assay were also strong inducers of $R A R \beta$ and 
CYP26A1. Nevertheless, in these experiments the CYP26A1 gene was induced to a much higher extent than the RAR $\beta$ gene. This could be because the CYP26A1 gene has two RAREs that work synergistically [54]. Furthermore, the basal levels of CYP26A1 expression were very low; hence, when the cells are treated with retinoids the fold increase in CYP26A1 will be very high compared to the fold change in $R A R \beta$.

In the ERK1/2 phosphorylation assays, several retinoids lacked the ability to phosphorylate ERK1/2, whereas others were more effective than ATRA. Use of this assay helped us to identify novel properties for many of these compounds and little connection was found between induction of genomic versus non-genomic signalling, suggesting that quite different pathways mediate these two activities. TTNPB, DC318, DC444 and JBGG179, which were potent activators of gene transcription, did not show any detectable capacity to induce ERK1/2 phosphorylation compared to ATRA. In contrast, HX600, DA124, EC19, CD2665, DC375, DC324, DC329, DC476 and DC479, which did not have genomic activity, induced ERK1/2 phosphorylation. In addition, we show that the RAR $\beta / \gamma$ antagonist CD2665 could act as an agonist for ERK $1 / 2$ phosphorylation. Moreover, two ligands for the RXR class of RA receptors (HX600 and DA124) induced ERK 1/2 phosphorylation, revealing a novel property of this class of ligand.

While the activities of the retinoids in the separate genomic and non-genomic assays suggest that these functions are determined by different structural properties, a key result is that retinoids with both genomic and non-genomic inducing activities had the highest enhancing effects on neurite outgrowth, while compounds with only one activity tended to induce neurite outgrowth with lower efficiency (Fig. 8a). For example, EC23, AH61 and GZ25, which had the greatest enhancing effect on neurite length, were also strong inducers of gene transcription and ERK1/2 phosphorylation. Retinoids with only one activity did not induce neurite formation at low $(10 \mathrm{nM})$ treatment concentrations.

When testing the correlation between retinoid transcriptional potency or ERK1/2 activation potency with neurite outgrowth or cell number, transcriptional activation activity correlated with neurite outgrowth and cell number while ERK1/2 potency correlated with neither. However, retinoids without detectable ERK1/2 induced significantly shorter neurites compared to retinoids with ERK1/2 inducing activity. Further, inhibitors of ERK1/2 activity blocked retinoid induced neurite outgrowth. These data indicate that ERK1/2 is required for retinoid-induced neurite outgrowth and influences length but it is potency of transcriptional activity of the retinoids that is directly proportional to neurite outgrowth. The induction of ERK $1 / 2$ activity by retinoids did not appear to influence cell number, although one mechanism by which retinoids increase number of SH-SY5Y cells is through increased cell survival in an ERK1/2 dependent mechanism [9]. Because the time scales of the ERK1/2 and transcriptional assays differ by an order of magnitude, and the neurite and cell-number responses are measured after 5 days, it would be premature to discount a continuing role of ERK $1 / 2$ in control of cell number. To address this issue adequately, time-course analyses guided by computational

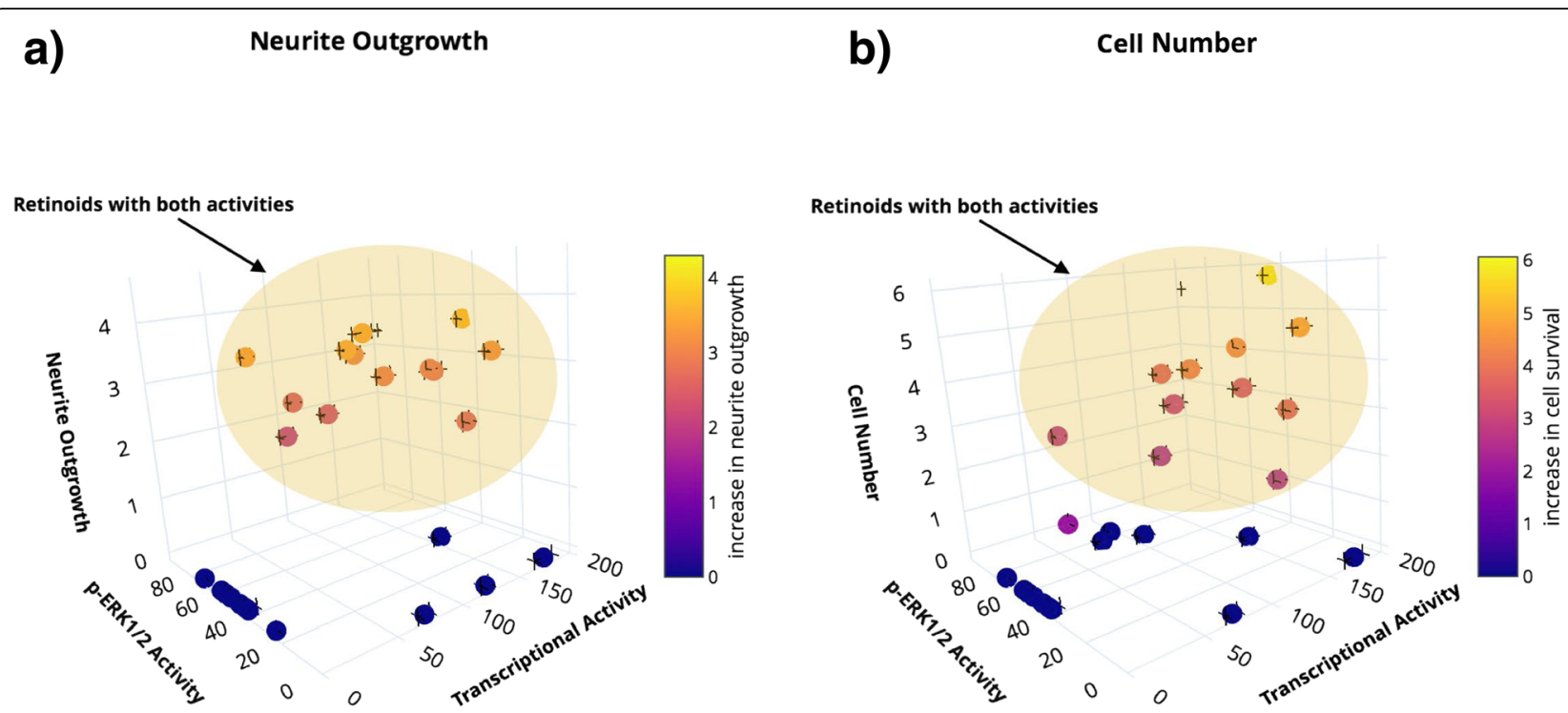

Fig. 8 The relationship between the genomic and non-genomic activities and neurite outgrowth and cell number in SH-SY5Y cells. Retinoids with both genomic and non-genomic inducing activities had the highest enhancing effects on $\mathbf{a})$ neurite outgrowth and $\mathbf{b}$ ) cell number 
modelling, coupled with bioinformatic approaches to data collection and analysis, will be required.

One mechanism by which ATRA promotes neurite outgrowth is through regulation of the transcription of neurotrophin genes, such as nerve growth factor (NGF) and brain derived neurotrophic factor (BDNF), which are important regulators of survival and neurite outgrowth $[55,56]$, and increasing the expression of TrkB, the receptor for BDNF in SH-SY5Y cells $[17,45]$. Furthermore, a number of genes that are downstream targets of ATRA genomic activity have been shown to function as neurite regulating factors [57-61].

A second mechanism of ATRA induced neurite outgrowth is through kinase activation. A number of kinase pathways have been associated with ATRA's ability to induce neurite outgrowth in neuroblastoma cells such as ERK1/2 [62, 63], c-Jun $N$-terminal kinase (JNK) [64-66] and PI3K [67]. The action in this study of the MEK1/2 inhibitor to reduce neurite outgrowth in EC23 and ATRA treated cells supports the importance of the MEK1/2-ERK1/2 pathway. These different kinase pathways have been shown to play an important role in cytoskeletal reorganization and the modulation of neurite outgrowth [56, 68]. For example, phosphorylated ERK1/ 2 regulates microtubule dynamics by phosphorylating different microtubule associated proteins and it also enters the nucleus and activates various transcription factors such as cAMP response element binding (CREB) protein required for axonal growth [56]. Yu and colleagues [66] reported that the JNK pathway plays a role in ATRA induced neurite outgrowth in SH-SY5Y cells as neurite outgrowth in the cells was repressed after inhibiting JNK. Lee and Kim [64] showed that the ERK pathway is essential for ATRA induced neurite outgrowth in SK-N-BE(2)C neuroblastoma cells. Additionally, it was reported that ATRA induced PI3K leads to the activation of the Rac1 G-protein, which is important for neuritogenesis and PI3K inhibition impaired ATRA induced neurite outgrowth in SH-SY5Y cells [67].

The routes by which the retinoids described in this study regulate non-genomic actions are very diverse, frequently rapid and involve a receptor in the cytoplasm. RAR $\alpha$ is particularly prominent in such a role. In the cytoplasm RAR $\alpha$ acts as an mRNA binding protein to regulate protein translation [53]. It is also present in lipid rafts of the plasma membrane (in MCF7 cells), and retinoic acid rapidly activated P38MAPK in MCF7, HeLa cells, F9 mouse embryocarcinoma cells and mouse embryonic fibroblasts with $\mathrm{Gq}$ protein $\alpha$ subunit acting as an intermediate [69]. Alternatively, in SH-SY5Y cells RAR $\alpha$, again at the plasma membrane, interacts with PI3K to activate ERK1/2 [70] while in the cytoplasm of neuronal LA-N-5 cells RARy interacts with c-src kinase to control neurite outgrowth [71]. The complexity of pathways does not end there. The cytoplasmic receptor for RA and related compounds mediating non-genomic actions do not necessarily need to be an RAR. For instance, a cytoplasmic function for RA in CJ7 embryonic stem cells and COS1 (kidney) cells to induce rapid ERK1/2 activation uses cellular retinoic acid binding protein 1 (CRABPI) [72]. RA can itself directly bind to kinases such as Protein kinase $\mathrm{C}$ alpha [73] while in the neuronal cell line PC12 CaMKII has a vital role to play in RA activation of ERK1/2 [74]. Thus, some of the actions of the compounds described in the study to activate ERK1/2 may not be through the RARs themselves.

\section{Conclusions}

This study showed that the tested retinoids varied in their ability to activate gene transcription and the non-genomic pathways via ERK1/2 activation, and that some compounds exhibit activity corresponding to the modulation of only a single pathway. Furthermore, ligands that activate both genomic and non-genomic pathways had the highest activity in assays for neuronal cell number and neurite outgrowth. Thus, such dual-potency retinoids can be developed in order to considerably enhance their activity as promoters of neurite outgrowth and neuronal cell number. Alternatively, retinoids with pathway specificity can be developed to potentially reduce side-effects. These results have important implication for the further development of these drugs for neurodegenerative disorders.

\section{Additional files}

Additional file 1: Table S1. Summary of effects of retinoids on the genomic, non-genomic and neurite outgrowth activities in SH-SY5Y cells. The $\mathrm{EC}_{50}$ value represents the half-maximal effective concentration and is related to the affinity for the RA receptor, while the maximum stimulation, which is defined by the $E_{\max }$ value, is a measure of compound efficacy. The $95 \%$ confidence intervals $(\mathrm{Cl})$ represents the predicted range of $E C_{50}$ and $E_{\max }$ values for a specific compound. Fold increase represents the increase in neurite formation compared to non-treated cells. (PDF $73 \mathrm{~kb}$ )

Additional file 2: Figure S1. Correlation analyses between the effects of retinoids (filled circles) on cell number, neurite length, transcriptional activity (Efficacy, $\left.E_{\max }\right)$ and ERK1/2 activity (Efficacy, $\left.E_{\max }\right)$. Lines (nonparametric median slopes) are only fitted where correlation coefficients (Pearson, or Spearman for ranked plots), as given in the main text, were significant $(P<0.05)$. a, cell number versus neurite length (fold change); $b$, ranked ERK1/2 activity versus ranked transcriptional activity for all retinoids; $c$, neurite length (fold change) versus ERK1/2 activity for retinoids that induced an increase in neurite length; $d$, ranked neurite length (fold change) versus ranked transcriptional activity for retinoids that induced an increase in neurite length; e, cell number (fold change) versus ERK1/2 activity for all retinoids; $f$, ranked cell number (fold change) versus ranked transcriptional activity for all retinoids. (DOCX $123 \mathrm{~kb}$ )

\section{Abbreviations}

ATRA: All-trans-retinoic acid; BDNF: Brain derived neurotrophic factor; $\mathrm{C}_{6} \mathrm{FeK}_{3} \mathrm{~N}_{6}$ : Potassium ferricyanide; $\mathrm{C}_{6} \mathrm{FeK}_{4} \mathrm{~N}_{6}$ : Potassium ferrocyanide; cDNA: Complement deoxyribonucleic acid; Cl: Confidence intervals; CT: Control, Untreated cells; CYP26: Cytochrome P450, family 26; 
DMEM: Dulbecco's Modified Minimum Essential Medium; DMSO: Dimethyl sulfoxide; DNA: Deoxyribonucleic acid; $\mathrm{EC}_{50}$ : Half maximal effective concentration; EDTA: Ethylenediaminetetraacetic acid; $\mathrm{E}_{\max }$ : Maximum possible effect for the agonist; ERK: Extracellular signal-regulated kinases; FCS: Fetal calf serum; g: Gram(s); GAPDH: Glyceraldehyde 3-phosphate dehydrogenase; GIMP: GNU image manipulation program; h: Hour(s); $\mathrm{HCl}$ : Hydrochloric acid; HNO3: Nitric acid; JNK: c-Jun N-terminal kinase; M: Molar; MEK1/2 : Mitogen-activated protein kinase kinase family member; mg: Milligram(s); $\mathrm{MgCl}_{2}$ : Magnesium chloride; min: Minute(s); ml: Millilitre(s); mm: Millimetre(s); mM: Millimolar; mRNA: Messenger ribonucleic acid; ng: Nanogram(s); NGF: Nerve growth factor; nm: Nanometre(s); nM: Nanomolar; PBS: Phosphate-buffered saline; PBST: Phosphate-buffered saline with $0.1 \%$ triton X-100; PCR: Polymerase chain reaction; pERK: Phosphorylated ERK; PFA: Paraformaldehyde; PI3K: Phosphoinositide 3kinase; PLL: Poly-L-lysine; qPCR: Quantitative polymerase chain reaction; RA: Retinoic acid; RAR: Retinoic acid receptor; RARE: Retinoic acid response element; RBP4: Retinol binding protein 4; RNA: Ribonucleic acid; RT: Reverse transcriptase; RXR: Retinoic X receptor; s: Second (s); SEM: Standard error of the mean; X-Gal solution: 5-Bromo-4-Chloro-3-Indolyl $\beta$-D-Galactopyranoside; $\mu \mathrm{g}$ : Microgram(s); $\mu \mathrm{l}$ : Microliter(s); $\mu \mathrm{M}$ : Micromolar; $\mu \mathrm{m}$ : Micron or Micrometre(s)

\section{Acknowledgements}

Not applicable.

\section{Funding}

Support was received from BBSRC grant BB/P004806/1.

\section{Availability of data and materials}

The datasets used and/or analysed during the current study are available from the corresponding author on reasonable request.

\section{Authors' contributions}

TK designed and performed experiments, analysed the data and prepared the first draft of the manuscript; PM helped to design experiments and revise the manuscript; SN helped with experimental design; DRC synthesised some of the RAR ligands used in the study and revised the manuscript; AW assisted with the design of experiments and revisions to the manuscript; $C R$ assisted with data interpretation and revisions to the manuscript; IG helped with experimental design and revisions to the manuscript; all authors read and approved the final manuscript.

\section{Authors' information}

Not applicable

\section{Ethics approval}

Animal use: All procedures conformed to Home Office regulations and local ethics committee guidelines.

\section{Consent for publication}

Not applicable.

\section{Competing interests}

The authors declare that they have no competing interests.

\section{Publisher's Note}

Springer Nature remains neutral with regard to jurisdictional claims in published maps and institutional affiliations.

\section{Author details}

${ }^{1}$ School of Medicine, Medical Sciences and Nutrition, Institute of Medical Sciences, University of Aberdeen, Foresterhill, Aberdeen AB25 2ZD, Scotland, UK. ${ }^{2}$ Department of Chemistry, Durham University, South Road, Durham DH1 3LE, UK. ${ }^{3}$ Northern Institute for Cancer Research, Medical School, Newcastle University, Newcastle upon Tyne NE2 4HH, UK.
Received: 8 January 2019 Accepted: 9 April 2019

Published online: 02 May 2019

\section{References}

1. Blomhoff R, Blomhoff HK. Overview of retinoid metabolism and function. Neurobiol [Internet]. 2006;66:606-30 Available from: https://onlinelibrary. wiley.com/doi/abs/10.1002/neu.20242.

2. Maden M. Retinoid signalling in the development of the central nervous system. Nat Rev Neurosci [Internet]. 2002;3:843-53 Available from: http:// www.nature.com/doifinder/10.1038/nrn963.

3. Pavlovic D, Markisic M, Pavlovic A, Lackovic M, Bozic M. Vitamin a and the nervous system. Arch Biol Sci [Internet]. 2014;66:1585-90 Available from: http://www.doiserbia.nb.rs/Article.aspx?!D=0354-46641404585P.

4. Chambon P. A decade receptors biology of retinoic acid. Faseb. 1996;10: 940-54.

5. Mey J, Mccaffery P. Retinoic acid signaling in the nervous system of adult vertebrates. Neurosci [Internet] 2004;10:409-421. Available from: http:// journals.sagepub.com/doi/10.1177/1073858404263520

6. Simoncini T, Genazzani AR. Non-genomic actions of sex steroid hormones. Eur J Endocrinol. 2003;148:281-92.

7. Valverde MA, Parker MG. Classical and novel steroid actions: a unified but complex view. Trends Biochem Sci. 2002:27:172-3.

8. Aggarwal S, Kim S-W, Cheon K, Tabassam FH, Yoon J-H, Koo JS. Nonclassical action of retinoic acid on the activation of the CAMP response elementbinding protein in normal human bronchial epithelial cells. Mol Biol Cell [Internet]. 2006;17:566-75 Available from: http://www.ncbi.nlm.nih.gov/ pubmed/16280361.

9. Waetzig V, Haeusgen W, Andres C, Frehse S, Reinecke K, Bruckmueller $\mathrm{H}$, et al. Retinoic acid-induced survival effects in SH-SY5Y neuroblastoma cells. J Cell Biochem [Internet]. 2019;120:5974-5986. Available from: http://doi.wiley. com/10.1002/jcb.27885

10. Giannì M, Bauer A, Garattini E, Chambon P, Rochette-Egly C. Phosphorylation by P38MAPK and recruitment of SUG-1 are required for RA-induced RARY degradation and transactivation. EMBO J. 2002;21:3760-9.

11. Bruck N, Vitoux D, Ferry C, Duong V, Bauer A, de Thé H, et al. A coordinated phosphorylation cascade initiated by p38MAPK/MSK1 directs RARa to target promoters. EMBO J [Internet]. 2009;28:34-47 Available from: http://emboj. embopress.org/cgi/doi/10.1038/emboj.2008.256.

12. Ochoa WF, Torrecillas A, Fita I, Verdaguer N, Corbalán-García S, GomezFernandez JC. Retinoic acid binds to the C2-domain of protein kinase Ca. Biochemistry. 2003:42:8774-9.

13. Cañón E, Cosgaya JM, Scsucova S, Aranda A. Rapid effects of retinoic acid on CREB and ERK phosphorylation in neuronal cells. Mol Biol Cell [Internet]. 2004;15:5583-92 Available from: http://www.molbiolcell.org/cgi/doi/10. 1091/mbc.E04-05-0439

14. Pan J, Kao Y-L, Joshi S, Jeetendran S, Dipette D, Singh US. Activation of Racl by phosphatidylinositol 3-kinase in vivo: role in activation of mitogenactivated protein kinase (MAPK) pathways and retinoic acid-induced neuronal differentiation of SH-SY5Y cells. J Neurochem [Internet]. 2005;93: 571-83 Available from: http://www.ncbi.nlm.nih.gov/pubmed/15836616.

15. Quinn SD, De Boni U. Enhanced neuronal regeneration by retinoic acid of murine dorsal root ganglia and of fetal murine and human spinal cord in vitro. In Vitro Cell Dev Biol [Internet]. 1991;27:55-62 Available from: http:// www.ncbi.n/m.nih.gov/pubmed/2013554.

16. Plum LA, Parada LF, Tsoulfas P, Clagett-Dame M. Retinoic acid combined with neurotrophin-3 enhances the survival and neurite outgrowth of embryonic sympathetic neurons. Exp Biol Med [Internet]. 2001;226:766-75 Available from: http://www.ncbi.nlm.nih.gov/pubmed/11520943.

17. Kaplan DR, Matsumoto K, Lucarelli E, Thiele CJ. Induction of TrkB by retinoic acid mediates biologic responsiveness to BDNF and differentiation of human neuroblastoma cells. Eukaryotic Signal Transduction Group. Neuron [Internet]. 1993;11:321-31. Available from: http://www.ncbi.nlm.nih.gov/ pubmed/8394722

18. Maden M, Keen G, Jones GE. Retinoic acid as a chemotactic molecule in neuronal development. Int J Dev Neurosci [Internet]. 1998;16:317-22 Available from: http://www.ncbi.nlm.nih.gov/pubmed/9829167.

19. Hunter K, Maden M, Summerbell D, Eriksson U, Holder N. Retinoic acid stimulates neurite outgrowth in the amphibian spinal cord. Proc Natl Acad Sci U S A [Internet]. 1991;88:3666-70 Available from: http://www.ncbi.nlm. nih.gov/pubmed/1850835. 
20. Sidell N, Altman A, Haussler MR, Seeger RC. Effects of retinoic acid (RA) on the growth and phenotypic expression of several human neuroblastoma cell lines. Exp Cell Res [Internet]. 1983;148:21-30 Available from: http://www. ncbi.nlm.nih.gov/pubmed/6313408.

21. Prince DJ, Carlone RL. Retinoic acid involvement in the reciprocal neurotrophic interactions between newt spinal cord and limb blastemas in vitro. Dev Brain Res. 2003;140:67-73.

22. Haffez H, Chisholm DR, Valentine R, Pohl E, Redfern C, Whiting A. The molecular basis of the interactions between synthetic retinoic acid analogues and the retinoic acid receptors. Med Chem Comm [Internet]. Royal Society of Chemistry; 2017;8:578-92. Available from: http://xlink.rsc org/?DOI=C6MD00680A

23. Clemens G, Flower KR, Gardner P, Henderson AP, Knowles JP, Marder TB, et al. Design and biological evaluation of synthetic retinoids: probing length vs. stability vs. activity. Mol Biosyst [Internet]. 2013;9:3124 Available from: http://xlink.rsc.org/?DOl=c3mb70273a.

24. Christie VB, Barnard JH, Batsanov AS, Bridgens CE, Cartmell EB, Collings JC, et al. Synthesis and evaluation of synthetic retinoid derivatives as inducers of stem cell differentiation. Org Biomol Chem [Internet]. 2008;6:3497 Available from: http://xlink.rsc.org/?DOI=b808574a.

25. Zhou G-L, Tams DM, Marder TB, Valentine R, Whiting A, Przyborski SA. Synthesis and applications of 2,4-disubstituted thiazole derivatives as small molecule modulators of cellular development. Org Biomol Chem [Internet] 2013;11:2323 Available from: http://xlink.rsc.org/?DOl=c3ob00005b.

26. Haffez H, Chisholm DR, Tatum NJ, Valentine R, Redfern C, Pohl E, et al. Probing biological activity through structural modelling of ligand-receptor interactions of 2,4-disubstituted thiazole retinoids. Bioorg Med Chem [Internet]. Elsevier Science; 2018;26:1560-72. Available from: http://www. ncbi.nlm.nih.gov/pmc/articles/PMC5933457/

27. Gluyas JBG, Burschka C, Dörrich S, Vallet J, Gronemeyer H, Tacke R. Disilaanalogues of the synthetic retinoids EC23 and TTNN: synthesis, structure and biological evaluation. Org Biomol Chem [Internet]. 2012;10:6914 Available from: http://xlink.rsc.org/?DOl=c2ob25989c.

28. Chisholm DR, Tomlinson CWE, Zhou G-L, Holden C, Affleck V, Lamb R, et al. Fluorescent retinoic acid analogues as probes for biochemical and intracellular characterization of retinoid signaling pathways. ACS Chem Biol [Internet] 2019;acschembio.8b00916. Available from: http://pubs.acs.org/doi/ 10.1021/acschembio.8b00916.

29. Wagner M, Han B, Jessell TM. Regional differences in retinoid release from embryonic neural tissue detected by an in vitro reporter assay. Development [Internet]. 1992;116:55-66 Available from: http://www.ncbi. nlm.nih.gov/pubmed/1483395.

30. de The H, Vivanco-Ruiz MM, Tiollais $\mathrm{P}$, Stunnenberg $\mathrm{H}$, Dejean A. Identification of a retinoic acid responsive element in the retinoic acid receptor beta gene. Nature [Internet]. 1990;343:177-80. Available from: https://www.ncbi.nlm.nih.gov/pubmed/2153268.

31. McCaffery P, Dräger UC. A sensitive bioassay for enzymes that synthesize retinoic acid. Brain Res Protocol. 1997;1:232-6.

32. Biedler $J$, Helson L, Spengler BA. Morphology and growth, tumorigenicity, and cytogenetics of human neuroblastoma cells in continuous culture. Cancer Res [Internet]. 1973;33:2643-52 Available from: http://www.ncbi.nlm. nih.gov/pubmed/4748425.

33. Biedler UL, Roffler-Tarlov S, Schachner M, Freedman LS. Multiple neurotransmitter synthesis by human neuroblastoma cell lines and clones. Cancer Res [Internet]. 1978;38:3751-7 Available from: http://www.ncbi.nlm.nih.gov/pubmed/29704.

34. Ye J, Coulouris G, Zaretskaya I, Cutcutache I, Rozen S, Madden TL. PrimerBLAST: a tool to design target-specific primers for polymerase chain reaction. BMC Bioinformatics. 2012;13:134.

35. Team RDC. R: a language and environment for statistical computing [internet]. Vienna, Austria : the R Foundation for statistical computing; 2016. Available from: http://www.r-project.org/.

36. Ray WJ, Bain G, Yao M, Gottlieb DI. CYP26, a novel mammalian cytochrome P450, is induced by retinoic acid and defines a new family. J Biol Chem [Internet]. 1997;272:18702-8 Available from: http://www.ncbi.nlm.nih.gov/ pubmed/9228041.

37. de The H, Marchio A, Tiollais P, Dejean A. Differential expression and ligand regulation of the retinoic acid receptor alpha and beta genes. EMBO J [Internet]. 1989;8:429-33. Available from: http://www.ncbi.nlm.nih.gov/ pubmed/2542014

38. Loudig O, Babichuk C, White J, Abu-Abed S, Mueller C, Petkovich M. Cytochrome P450RAI(CYP26) promoter: a distinct composite retinoic acid response element underlies the complex regulation of retinoic acid metabolism. Mol Endocrinol [Internet]. 2000;14:1483-97 Available from: https://academic.oup.com/mend/article-lookup/doi/10.1210/mend.14.9.0518.

39. Alique M, Herrero JF, Lucio-Cazana FJ. All-trans retinoic acid induces COX-2 and prostaglandin E2 synthesis in SH-SY5Y human neuroblastoma cells: involvement of retinoic acid receptors and extracellular-regulated kinase 1/ 2. J Neuroinflammation. 2007:4:1-9.

40. Cheung Y-T, Lau WK-W, Yu M-S, Lai CS-W, Yeung S-C, So K-F, et al. Effects of all-trans-retinoic acid on human SH-SY5Y neuroblastoma as in vitro model in neurotoxicity research. Neurotoxicology [Internet]. 2009;30:127-35 Available from: http://linkinghub.elsevier.com/retrieve/pii/ S0161813X08002003.

41. Qiao J, Paul P, Lee S, Qiao L, Josifi E, Tiao JR, et al. PI3K/AKT and ERK regulate retinoic acid-induced neuroblastoma cellular differentiation. Biochem Biophys Res Commun [Internet]. 2012;424:421-6 Available from: http://linkinghub.elsevier.com/retrieve/pii/S0006291X12012272.

42. Li Z, Theus MH, Wei L. Role of ERK $1 / 2$ signaling in neuronal differentiation of cultured embryonic stem cells. Dev Growth Differ [Internet]. 2006;48:51323 Available from: http://doi.wiley.com/10.1111/j.1440-169X.2006.00889.x.

43. Singh US, Pan J, Kao Y-L, Joshi S, Young KL, Baker KM. Tissue transglutaminase mediates activation of RhoA and MAP kinase pathways during retinoic acid-induced neuronal differentiation of SH-SY5Y cells. J Biol Chem [Internet]. 2003;278:391-9 Available from: http://www.jbc.org/lookup/ doi/10.1074/jbc.M206361200

44. Nicolini G, Miloso M, Zoia C, Di Silvestro A, Cavaletti G, Tredici G. Retinoic acid differentiated SH-SY5Y human neuroblastoma cells: an in vitro mode to assess drug neurotoxicity. Anticancer Res [Internet]. 1998;18:2477-81 Available from: http://www.ncbi.nlm.nih.gov/pubmed/9703895.

45. Encinas M, Iglesias M, Liu Y, Wang H, Muhaisen A, Ceña V, et al. Sequential treatment of SH-SY5Y cells with retinoic acid and brain-derived neurotrophic factor gives rise to fully differentiated, neurotrophic factor-dependent, human neuron-like cells. J Neurochem [Internet]. 2002;75:991-1003 Available from: http://doi.wiley.com/10.1046/j.1471-4159.2000.0750991.x.

46. Lovat PE, Oliverio S, Ranalli M, Corazzari M, Rodolfo C, Bernassola F, et al. GADD153 and 12-lipoxygenase mediate fenretinide-induced apoptosis of neuroblastoma. Cancer Res [Internet]. 2002;62:5158-67 Available from: http://www.ncbi.nlm.nih.gov/pubmed/12234979.

47. Hewson QDC, Lovat PE, Corazzari M, Catterall JB, Redfern CPF. The NF-KB pathway mediates fenretinide-induced apoptosis in SH-SY5Y neuroblastoma cells. Apoptosis [Internet]. 2005;10:493-8 Available from: http://link.springer. com/10.1007/s10495-005-1878-z.

48. Lovat PE, Ranalli M, Annichiarrico-Petruzzelli M, Bernassola F, Piacentini M, Malcolm AJ, et al. Effector mechanisms of Fenretinide-induced apoptosis in neuroblastoma. Exp Cell Res [Internet]. 2000;260:50-60 Available from: http://linkinghub.elsevier.com/retrieve/pii/S0014482700949887.

49. Petkovich M, Brand NJ, Krust A, Chambon P. A human retinoic acid receptor which belongs to the family of nuclear receptors. Nature [Internet]. 1987;330:44450 Available from: http://www.nature.com/doifinder/10.1038/330444a0.

50. Altucci L, Leibowitz MD, Ogilvie KM, de Lera AR, Gronemeyer H. RAR and RXR modulation in cancer and metabolic disease. Nat Rev Drug Discov [Internet]. 2007;6: 793-810 Available from: http://www.nature.com/doifinder/10.1038/nrd2397.

51. Ordóñez-Morán P, Muñoz A. Nuclear receptors: genomic and non-genomic effects converge. Cell Cycle. 2009;8:1675-80.

52. Masiá S, Alvarez S, de Lera AR, Barettino D. Rapid, nongenomic actions of retinoic acid on phosphatidylinositol-3-kinase signaling pathway mediated by the retinoic acid receptor. Mol Endocrinol. 2007;21:2391-402.

53. Poon MM, Chen L. Retinoic acid-gated sequence-specific translational control by RAR. Proc Natl Acad Sci [Internet]. 2008;105:20303-20308. Available from: https://www.pnas.org/content/105/51/20303

54. Loudig O, Maclean GA, Dore NL, Luu L, Petkovich M. Transcriptional cooperativity between distant retinoic acid response elements in regulation of Cyp26A1 inducibility. Biochem J [Internet]. 2005;392:241-8 Available from: https://www.ncbi.nlm.nih.gov/pmc/articles/PMC1317683/.

55. Davies AM. Neurotrophins: neurotrophic modulation of neurite growth. Curr Biol. 2000;10:198-200.

56. Markus A, Patel TD, Snider WD. Neurotrophic factors and axonal growth Curr Opin Neurobiol. 2002;12:523-31.

57. Sparatore B, Patrone M, Passalacqua M, Pedrazzi M, Pontremoli S, Melloni E. Human neuroblastoma cell differentiation requires protein kinase C-theta. Biochem Biophys Res Commun [Internet]. 2000;279:589-94 Available from: http://www.ncbi.nlm.nih.gov/pubmed/11118330. 
58. Tucholski J, Lesort M, Johnson GV. Tissue transglutaminase is essential for neurite outgrowth in human neuroblastoma SH-SY5Y cells. Neuroscience. 2001;102:481-91.

59. Nakamura Y, Ozaki T, Ichimiya S, Nakagawara A, Sakiyama S. Ectopic expression of DAN enhances the retinoic acid-induced neuronal differentiation in human neuroblastoma cell lines. Biochem Biophys Res Commun [Internet]. 1998;243: 722-6 Available from: http://www.ncbi.nlm.nih.gov/pubmed/9500977.

60. Merrill RA, See AWM, Wertheim ML, Clagett-Dame M. Crk-associated substrate (Cas) family member, NEDD9, is regulated in human neuroblastoma cells and in the embryonic hindbrain by all-trans retinoic acid. Dev Dyn. 2004;231:564-75.

61. Merrill RA, Plum LA, Kaiser ME, Clagett-Dame M. A mammalian homolog of unc-53 is regulated by all-trans retinoic acid in neuroblastoma cells and embryos. Proc Natl Acad Sci U S A [Internet]. 2002;99:3422-7 Available from: http://www.pubmedcentral.nih.gov/articlerender.fcgi?artid=122539\&tool= pmcentrez\&rendertype $=$ abstract.

62. Miloso M, Villa D, Crimi M, Galbiati S, Donzelli E, Nicolini G, et al. Retinoic acid-induced neuritogenesis of human neuroblastoma SH-SY5Y cells is ERK independent and PKC dependent. J Neurosci Res [Internet]. 2004;75:241-52 Available from: http://doi.wiley.com/10.1002/jnr.10848.

63. Encinas $\mathrm{M}$, Iglesias $\mathrm{M}$, Llecha N, Comella JX. Extracellular-regulated kinases and phosphatidylinositol 3-kinase are involved in brain-derived neurotrophic factor-mediated survival and neuritogenesis of the neuroblastoma cell line SH-SY5Y. J Neurochem. 1999;73:1409-21.

64. Lee JH, Kim KT. Induction of cyclin-dependent kinase 5 and its activator p35 through the extracellular-signal-regulated kinase and protein kinase a pathways during retinoic-acid mediated neuronal differentiation in human neuroblastoma SK-N-BE(2)C cells. J Neurochem. 2004;91:634-47.

65. Eom D-S, Choi W-S, Ji S, Cho JW, Oh YJ. Activation of C-Jun N-terminal kinase is required for neurite outgrowth of dopaminergic neuronal cells. Neuroreport [Internet]. 2005;16:823-8 Available from: http://www.ncbi.nlm. nih.gov/pubmed/15891578

66. Yu Y-M, Han P-L, Lee J-K. JNK pathway is required for retinoic acid-induced neurite outgrowth of human neuroblastoma, SH-SY5Y. Neuroreport [Internet]. 2003;14:941-5 Available from: http://www.ncbi.nlm.nih.gov/ pubmed/12802179.

67. López-Carballo G, Moreno L, Masiá S, Pérez P, Barettino D. Activation of the phosphatidylinositol 3-kinase/Akt signaling pathway by retinoic acid is required for neural differentiation of SH-SY5Y human neuroblastoma cells. J Biol Chem. 2002;277:25297-304.

68. Song H, Poo M. The cell biology of neuronal navigation. Nat Cell Biol. 2001;3:81-8.

69. Piskunov A. Rochette-Egly C. a retinoic acid receptor RARa pool present in membrane lipid rafts forms complexes with $\mathrm{G}$ protein aQ to activate p38MAPK. Oncogene [internet]. Nat Publ Group. 2012;31:3333-45 Available from: https://doi.org/10.1038/onc.2011.499.

70. Masiá S, Alvarez S, de Lera AR, Barettino D. Nongenomic actions of retinoic acid on Phosphatidylinositol-3-kinase signaling pathway mediated by the retinoic acid receptor. Mol Endocrinol [Internet]. 2007;21:2391-402 Available from: https:/academic.oup.com/mend/article-lookup/doi/10.1210/me.20070062.

71. Dey N, De PK, Wang M, Zhang H, Dobrota EA, Robertson KA, et al. CSK Controls Retinoic Acid Receptor (RAR) Signaling: a RAR-c-SRC Signaling Axis Is Required for Neuritogenic Differentiation. Mol Cell Biol [Internet]. 2007;27: 4179-97. Available from: http://mcb.asm.org/cgi/doi/10.1128/MCB.01352-06

72. Persaud SD, Lin Y-W, Wu C-Y, Kagechika H, Wei L-N. Cellular retinoic acid binding protein I mediates rapid non-canonical activation of ERK1/2 by alltrans retinoic acid. Cell Signal [Internet]. 2013;25:19-25 Available from: https://www.ncbi.nlm.nih.gov/pmc/articles/PMC3508141/.

73. Radominska-Pandya A, Chen G, Czernik PJ, Little JM, Samokyszyn VM, Carter CA, et al. Direct interaction of all-trans-retinoic acid with protein kinase $C$ (PKC): implications for PKC signaling and cancer therapy. J Biol Chem. 2000; 275:22324-30

74. Liu J, Zhou R, He Q, Li W-I, Zhang T, Niu B, et al. Calmodulin kinase II activation of mitogen-activated protein kinase in PC12 cell following alltrans retinoic acid treatment. Neurotoxicology [Internet]. 2009;30:599-604 Available from: https://linkinghub.elsevier.com/retrieve/pii/ S0161813X09000771.

\section{Ready to submit your research? Choose BMC and benefit from:}

- fast, convenient online submission

- thorough peer review by experienced researchers in your field

- rapid publication on acceptance

- support for research data, including large and complex data types

- gold Open Access which fosters wider collaboration and increased citations

- maximum visibility for your research: over $100 \mathrm{M}$ website views per year

At BMC, research is always in progress.

Learn more biomedcentral.com/submissions 